\title{
Dairy production system type and critical points of contamination
}

\section{Tipologia de sistemas de produção leiteiros e pontos críticos de contaminação}

\author{
Gilberto Henrique Simões ${ }^{1 *}$; Magali Soares dos Santos Pozza ${ }^{2}$; Maximiliane \\ Alavarse Zambom ${ }^{3}$; Maichel Jhonattas Lange ${ }^{1}$; Marcelo Eduardo Neumann ${ }^{1}$
}

\begin{abstract}
Current milk production includes a large diversity between systems, which generates difficulties in defining a microbiological standard. The adapted practical and hygienic-sanitary management methods are diverse and introduce great complexity into the production systems. Based on this scenario, the objective of this study was to evaluate the types of dairy production systems of western Parana and to quantify Staphylococcus $s p$ in three critical points in the dairy cattle production systems: the milking machines, milkers' hands, the cooling tanks and raw milk. A total of 35 samples of refrigerated raw milk were collected, and a questionnaire referring to hygienic and sanitary management was administered. All of the data were collected during the period from September to October 2012 and involved 35 properties in the municipality of Marechal Cândido Rondon - PR. From these data, five groups were formed based on cluster analysis (CHA). The multiple correspondence analysis (MCA) presented in the first two dimensions, CP1 (81.43\%) and CP2 (36.87\%), showed the relevance of the variables used, which are sanitary and production management methods, and contamination and control of mastitis, respectively (CP1 and CP2). We found average contamination with $9.9 \times 10^{1} \mathrm{CFU} / \mathrm{cm}^{2}, 2.2 \times 10^{4} \mathrm{CFU} / \mathrm{cm}^{2}, 28 \mathrm{CFU} /$ $\mathrm{cm}^{2}$ and $3.8 \times 10^{3} \mathrm{CFU} / \mathrm{mL}$; for milking machines, milkers' hands, cooling tanks and milk, respectively. The results reveal the presence of staphylococcal agent in dairy production systems regardless of the adopted hygiene and health management protocols. The guidance, planning and adaptation of hygiene and health management systems can significantly improve the microbiological quality of the milk produced, both qualitatively and quantitatively.
\end{abstract}

Key words: MCA, staphylococci, dairy cattle, hygienic and sanitary management, questionnaire

\section{Resumo}

A produção leiteira atual possui diversidade em seus sistemas existentes, ao gerar e proporcionar dificuldades em um padrão principalmente microbiológico. As práticas e manejos higiênico-sanitários adotadas são diversas e acarretam grande complexidade na evolução e melhora dos sistemas de produção. Com base nestes problemas, o objetivo do trabalho foi avaliar os tipos de sistemas de produção leiteiros da microrregião oeste do Paraná e quantificar Staphylococcus sp. em três pontos críticos na produção: ordenhadeira, mão-do-ordenhador, tanque de resfriamento e leite. Foram coletas 35 amostras de leite cru refrigerado conjuntamente com um guia semiestruturado referente ao manejo higiênico-sanitário existente, no período de setembro-outubro de 2012 no município de Marechal Cândido Rondon - PR. A partir destes dados (35 Sistemas de Produção Leiteiros), foram formados 5 grupos, conforme técnica de análise de clusters (CHA). A análise de correspondências múltiplas (ACM), apresentou nas duas primeiras

1 Discentes do Curso de Mestrado, Programa de Pós-Graduação em Zootecnia, Universidade Estadual do Oeste do Paraná, UNIOESTE, Marechal Cândido Rondon, PR, Brasil. E-mail: gilbertohs@gmail.com; maichel_j1@hotmail.com; marcelo. neumann@hotmail.com

2 Prof Adjunto, Universidade Estadual de Maringá, UEM, Maringá, PR, Brasil. E-mail: pozzamagali@yahoo.com.br

3 Prof Adjunto, UNIOESTE, Marechal Cândido Rondon, PR, Brasil. E-mail: mazambom@hotmail.com

Author for correspondence 
dimensões, CP1 (81,43\%) e CP2 (36,87\%), importância para a explicação das variáveis utilizadas, sendo estas de produção e manejos higiênicos; e contaminações e controle de mastite, na devida ordem

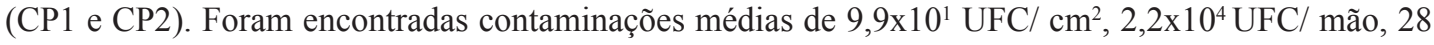
$\mathrm{UFC} / \mathrm{cm}^{2}$ e $3,8 \times 10^{3} \mathrm{UFC} / \mathrm{mL}$; para ordenhadeira, mãos dos ordenhadores, tanque de resfriamento e leite respectivamente. Os resultados encontrados revelam a presença do agente estafilococos nos sistemas de produção leiteiros, independentemente dos manejos higiênico-sanitários adotados. A orientação, planejamento e adequação dos manejos higiênico-sanitários podem melhorar significativamente a qualidade microbiológica do leite produzido, tanto qualitativamente quanto quantitativamente.

Palavras-chave: ACM, estafilococos, leite, ordenha, questionário, tanque

\section{Introduction}

Milk quality is one of the aspects of greatest relevance in the dairy production chain, especially given the higher inspection of the industrial sector and the increasing demand for high quality dairy products by consumers (REIS et al., 2007). Tracking critical points of contamination and the pursuit of proper hygiene and sanitary management has been ongoing for decades, but standard have yet to be established. This situation is even more critical in the Brazilian scenario due to the heterogeneity of the production systems and to the dimension of the country.

Among raw milk quality parameters, the somatic cell count (SCC) and total bacterial count (TBC) are the most important. The legislation, in this case normative instruction 62 (IN 62), provides quality criteria and sets deadlines for the achievement of these quality parameters for the whole national territory. In southern Brazil, the tolerance limits of contamination are numerically listed as $6.0 \times 10^{5}$ somatic cells $/ \mathrm{mL}$ and $6.0 \times 10^{5}$ colony-forming units/ $\mathrm{mL}$ for refrigerated raw milk, in addition to some specific physicochemical characteristics (BRASIL, 2011).

Nero et al. (2009) confirmed that the main parameter used to demonstrate the quality of this product is the microbiological profile, influenced mainly by the methods for obtaining, storing and transporting milk. It is known that there are many variables that interfere negatively with milk quality, and some of these variables require more research, such as milk contamination.
Milk contamination status can be used for the evaluation of its intrinsic quality, the sanitary conditions during the production and herd health (GUERREIRO et al., 2005). According to Santos and Fonseca (2001), after milking, milk can be contaminated by microorganisms from three main sources; within the mammary gland, the outer surface of the udder and equipment surfaces.

The quality criteria are increasingly used to detect failures in the management practices and to set prices for raw milk (GONZALEZ et al., 2004). The depth of knowledge of critical points of contamination during management is important, as this knowledge can directly influence the improvement of quality in the final product.

It is known that the degradation of proteins, fats and sugars are caused by bacteria, in particular, by bacteria of the mesophilic and psychrotrophic groups (BRITO; BRITO, 1998). Both have particular temperature characteristics, predilection sites, agents and synthesis of degrading enzymes; some can be highly pathogenic and significantly alter the sensory and physicochemical characteristics of milk. Therefore, the objective of this study was to obtain information through semi-structured questionnaires regarding the types of dairy production systems used in West Paraná to stratify the types of dairy production systems into homogeneous groups using multiple correspondence analysis (MCA) and clustering analysis (CHA). Additionally, we aimed to evaluate the microbiological quality of milk from different dairy production systems by measuring staphylococci in the milk and at three critical points of contamination: milkers' hands, milking machines and cooling tanks, in western Paraná. 


\section{Materials and Methods}

This research and data collection were carried out in the municipality of Marechal Cândido Rondon, located in the western region of the State of Paraná, Brazil. Data collection and sampling were performed from September to October of 2012. The municipality belongs to the Third Paraná Plateau (Plateau Guarapuava), and has a predominantly humid subtropical climate (CFA) according to Koppen, with hot summers, few frosts and a concentration of rainfall in the summer months (IAPAR, 1994). The soil consists of ferric oxisol, red clay soil and litholic Neosol (CUNHA; MORESCO, 2003). The average rainfall is 1700 $\mathrm{mm}$, with October being the wettest month and July the driest, with an average annual temperature of 21 ${ }^{\circ} \mathrm{C}$ (PARANÁ, 1998).

Primary data collection consisted of interviews administered with the aid of semistructured questionnaires to guide the producers (DAMASCENO et al., 2008; SOLANO et al., 2000; DEDIEU et al., 1997). We collected basic information about the types of dairy production systems, production management methods and production peculiarities involved in these properties. We evaluated 735 Dairy Production Systems (SPLs).

After primary data collection, and with the help of multivariate statistical techniques, including the analysis of multiple correspondence (MCA) and hierarchical cluster analysis (CHA), the SPLs were divided into five homogeneous groups. After the formation of the groups, we randomly chose $10 \%$ of producers in each group, totaling 73 selected properties.

We then conducted secondary data collection (using the attached semi-structured questionnaire guide) and collected a first milk sample from the tanks of the 73 properties to measure the somatic cell count test (SCC) and the total bacterial count (TBC). The questionnaire was designed to assess the production system, hygienic-sanitary characteristics and storage. The milk samples were packaged in standardized $70-\mathrm{mL}$ bottles and were transported and refrigerated (maximum $5{ }^{\circ} \mathrm{C}$ ) until the time of analysis. One of the vials contained the preservative Bronopol ${ }^{\circledR}$ (2-bromo-2-nitropropane-1,3-diol) for SCC and the other vial contained the preservative Azidiol ${ }^{\circledR}$, which was used for TBC.

Analyses were performed in the Holstein Cattle Breeders Association of Paraná - APCBRH, using the Somacount $500 \AA$ equipment for the SCC test and Bactocount IBC ${ }^{\circledR}$ to quantify the TBC.

From this group of 73 , we assessed which properties exceeded the SCC and/or TBC 62 IN standards of $6.0 \times 10^{5}$ cells $/ \mathrm{mL}$ and $6.0 \times 10^{5} \mathrm{CFU} /$ $\mathrm{mL}$, respectively. Thirty-five properties that did not meet the minimum limits established by the legislation were grouped for subsequent sample collection.

After the screening of the properties was completed, a third round of data collection and a second milk sampling procedure were undertaken. In this third step, we administered a new semistructured guide to the producers at the time of sample collection, during September to October 2012.

The questionnaires were prepared by teachers and students, based on previous studies, and were adapted according to the cultural and local realities of milk production in the region in question. The questions, responses and options following the questions were identical for all respondents (SILVA et al., 2013; DAMASCENO et al., 2008).

The questionnaire was based on the knowledge of the basic characteristics of production, and especially of the hygienic-sanitary management system, to qualify the properties based on their productive diversity. The variables addressed the characteristics of the producer, the property, herd composition, production, milking management, equipment and utensil cleaning practices, and bonuses for milk quality (NERO et al., 2009). 
Samples were collected by swabbing critical points of contamination that have a high influence on the microbiological quality of milk. The three selected points were the milking machines, milkers' hands and storage tanks. In addition, milk was collected for subsequent microbiological laboratory analyses. All swabs were packaged in vials with 9 $\mathrm{mL}$ of sterile peptone water in a refrigerated cool box (to $5^{\circ} \mathrm{C}$ ), together with the standardized milk distributed into 200-mL vials.

Microbiological analysis was performed in the UNIOESTE microbiology laboratory on the Marechal Cândido Rondon campus. After collection, serial decimal dilutions were prepared containing sterile peptone water in a test tube, to $10^{-3}$ for each contamination point, and milk-only dilutions were performed until $10^{-2}$. After the appropriate dilution and homogenization, aliquots of $100 \mu \mathrm{L}$ of each dilution were inoculated on Petri plates containing Baird Paker culture and were incubated at $37{ }^{\circ} \mathrm{C}$ for 48 hours for further reading and counting of colony forming units (CFU) of staphylococcus.

Multiple correspondence analysis (MCA) is a multivariate statistical analysis used to select a set of variables. According to Kubrusly (2001), the variables that have the greatest contribution of scores are included in the formation of the principal component (PC) and are described in terms of the explained variance and a Cronbach- $\alpha$ value $>0.75$ for the adjusted data. Based on these criteria, 35 variables were defined at respective occurrence levels.

Statistical analyses were performed using IBM SPSS Statistics 20.0 software; and included multiple correspondence analysis (MCA), hierarchical clusters analyses (CHA) and descriptive statistics of both the quantitative and qualitative variables (ANDRADE et al., 2009; MACHADO et al., 2000; OLIVEIRA et al., 2007a).

\section{Results and Discussion}

In the multiple correspondence analysis (MCA), we defined two components: the main component 1 (CP1) and component 2 (CP2), with variances of $81.43 \%$ and $36.87 \%$, respectively. The variable relations of the SPLs and the two dimensions formed by the set of their contributions explain the characterization of the 35 properties identified in the west Paraná region in relation to their hygienicsanitary management and crucial contamination points for milk quality (Figure 1).

The formation of CP1 included daily production, the number of dairy cows, location after milking, milking type, utilization of pre- and post-dipping and the use of alkaline and acid detergent on the cleaning equipment. These variables are dependent of the production volume and technology, with correct practices of hygiene in milking leading to higher quality of the final product.

According to Fonseca and Santos (2001), predipping can reduce new infections of the mammary glands, caused by environmental pathogens, by up to $50 \%$, and post-dipping is the most important practice in the control of new mammary infections. Cleaning equipment used for milk production consists of the removal of debris from the surface, and delaying this procedure may lead to a proliferation of microorganisms, which are consequently difficult to remove (CERQUEIRA et al., 2006).

The CP2 composition of the main determinant variables were preventive treatment for mastitis in dry cows, milk contamination, the evaluation of the presence of milk lumps, contamination during milking, and cleaning of the udder/teats before milking. One can understand that the most relevant variables for the formation of this second dimension are directly related to the hygienic practices applied to the animals and equipment to reduce the microbial load to prevent mastitis. Cavalcanti et al. (2010) emphasize that proper hygiene during milking including the cleaning, immersion in antiseptic solution and complete drying of teats is essential for the maintenance of milk bacterial quality. 
Figure 1. The variables and their contribution to the formation of MCA dimensions.

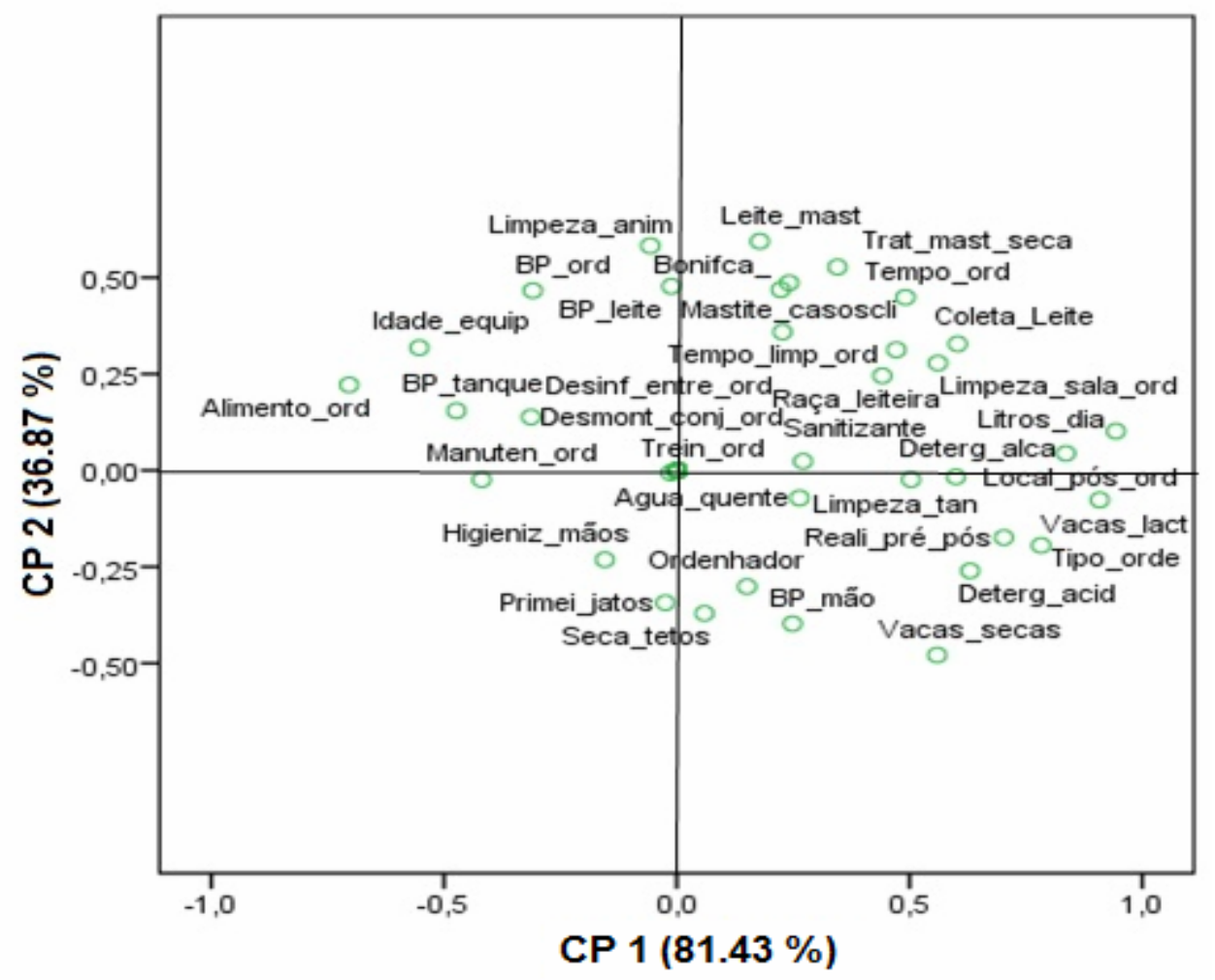

Legend: Vacas_lact: Dairy cows, Vacas_sec: Dry cows, Litros_dia: Liters day, Tipo_orde: milking type, Raça_leiteira: Dairy breed, Limpeza_anim: udder clening, Primei_jatos: first jets, Reali_pré_pós: Pre and pos dipping, Seca_tetos: drying teats, Alimento_ord: feeding while milking, Tempo_ord: milking lenght, Local_pós_ord: Place after milking, Desinf_entre_ord: desinfectant between milking, Trat mast seca: Prevention matitis dry cow, Mast_casoscli: Treatment for clinic mastitis, Leite mast: mastitic milk, Agua_quente: hot water, Desmont_conj: disassembling the set, Deterg_alca: alkaline detergent, Deterg_acid: Acid detergent, Sanit: Sanitizing, Limpeza_tan: cleaning of the tank, Limpeza_sala_ord: cleaning the milking place, Tempo_limp_ord: time length for cleaning the milking machine, Manut_ord: Maintenance of the milking machine, Orden: Milker, Higieniz_mãos: hygiene of the hands, Temp_tan: Tank temperature, Col_leite: Milk delivery, Trein_ord: molker training, Idade_equip: age of the equipment, Bonifica: Quality payment, BP_ord: Total staphylococci in the milking machine, BP_mao: Total staphylococci in the milker's hands, BP_tanque: Total staphylococci in the cooling tank, BP_leite: Total staphylococci in the milk.

With the displacement of the axis $\mathrm{X}(\mathrm{CP} 1)$ to its negative side, there are variables related to the maintenance and hygiene of equipment, including the time of equipment use, the maintenance and dismantling of sets of the milking machine for cleaning, and contamination of the milking machine and cooling tank. According to Müller (2002), the operation and maintenance of milking equipment has a strong influence on mastitis control programs, and requires staff training.

The variables related to the management of the milking machine such as drying the teats, milkers' hand hygiene and the elimination of the first milk jets are linked to the $\mathrm{Y}$ axis $(\mathrm{CP} 2)$ on the negative side. These factors have a direct interference on milk quality, especially on the TBC. The milk produced without hygienic practices becomes an inferior product, even when subsequently performing proper treatment (PERIN et al., 2009). The properties studied on this side of the axis include having few lactating cows, small production, deficient hygienesanitary management, and not using recommended techniques.

Problems detected in the milking practice among these properties are related to the nonapplication of recommended techniques and with 
the ignorance of their benefits for the quality of the final product. According to Valeeva et al. (2005), in small properties, you can view, in general, a higher frequency of deficiencies in production due to low investment in the activity, resulting in problems in the production chain. In this study, SPLs that produced less than $100 \mathrm{~L}$ /day were those who performed hygienic-sanitary practices less frequently (elimination of the first jets, pre- and postdipping, immersing the milking sets in sanitizing solution and using alkaline and acidic detergents).

According to the characterization of the SPLs and the typologies generated from the MCA, the
SPLs were classified into five groups using cluster analysis (Figure 2): Group 1 (G1) included 12 SPLs, Group 2 (G2) included 11 SPLs, Group 3 (G3) included eight SPLs, Group 4 (G4) included three SPLs, and Group 5 (G5) included only one SPLs. G1 is characterized by properties that have adequate hygienic-sanitary management practices, lower rates of contamination and generally high productivity (310 L/SPLs/day and $14.8 \mathrm{~L} /$ cow/day). On the chart, these properties fell to the center right. This group represents the most efficient SPLs, and $75 \%$ of SPLs received quantity and quality bonuses as an incentive for production.

Figure 2. The types of SPLs and their respective groups on the factorial plan for MCA.

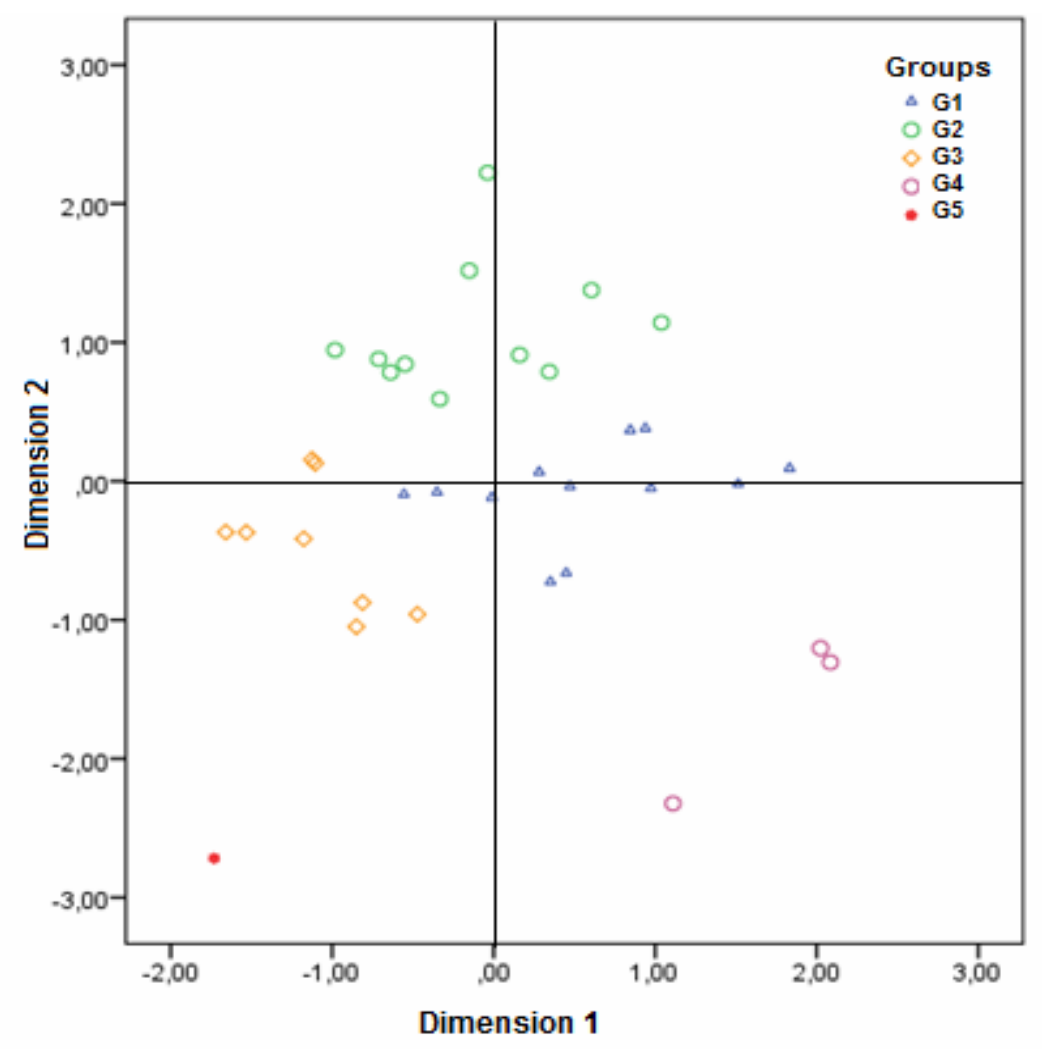

G2 and G3 were very similar. The main difference was the volume of milk produced. G3 included small properties that produced a maximum of $85 \mathrm{~L} /$ day. In contrast, $\mathrm{G} 2$ included properties that produced 50 to 400 L days, but both G2 and G3 had similar hygienic-sanitary practices.
G4 included systems with high production (660 L/SPLs/day) and an average of 45 lactating cows. Despite the high use of technology, due to untrained workers, these properties had difficulties in developing correct hygienic-sanitary techniques. 
Only one SPLs formed G5. Hygienic management practices were not carried out and daily production was very low (18 L/day) at this facility. The nonexecuted practices included detaching the milking sets, the use of alkaline and acid detergent, the use of sanitizer, conducting pre- and post-dipping and investigating and eliminating mastitic milk. The results of this study corroborate with the findings of Lopes Junior et al. (2012) and Bodenmüller Filho et al. (2010), who found homogeneous groups with productive features, poor management techniques, and low quality technical systems with management problems among low production properties.

The groups differed mainly by their production and adapted hygienic-sanitary management techniques. The largest percentage of SPLs that had good production and hygienic and sanitary characteristics were also those with higher yields, and comprised only $42.85 \%$ (15 SPLs) of total facilities.

The two milk samples were evaluated for SCC and TBC (Table 1). In G1, 41.6\% of the SPLs were compliant with the standards, but the group averages were unchanged from 1,181 cells $/ \mathrm{mL}^{-1}$ to 1,123 cells $/ \mathrm{mL}^{-1}$ between collections. We found a $25 \%$ increase at the second collection. The SPLs belonging to G1 had the best hygienic-sanitary management practices, and the results of the counts identified possible animals with subclinical mastitis and negligence during the cleaning of the equipment.

Table 1. The mean SCC and TBC levels, and the percentage of properties above the limits established by IN 62 , including data from two milk samples from each dairy production system.

\begin{tabular}{|c|c|c|c|c|c|}
\hline Groups & $\begin{array}{l}\text { Number of } \\
\text { Properties }\end{array}$ & $\begin{array}{c}\mathrm{SCC} 1^{\circ} \\
\text { mil cells } / \mathrm{mL}\end{array}$ & $\begin{array}{c}\mathrm{SCC} 2^{\circ} \\
\text { mil cells } / \mathrm{mL}\end{array}$ & $\begin{array}{c}\text { TBC }^{\circ} \\
\text { mil CFU/mL }\end{array}$ & 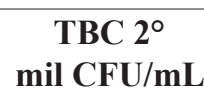 \\
\hline 1 & 12 & $\begin{array}{c}1181 \\
(91.6 \%) \\
\end{array}$ & $\begin{array}{c}1123 \\
(50.0 \%) \\
\end{array}$ & $\begin{array}{c}343 \\
(16.6 \%) \\
\end{array}$ & $\begin{array}{c}1535 \\
(41.6 \%) \\
\end{array}$ \\
\hline 2 & 11 & $\begin{array}{c}1165 \\
(81.8 \%)\end{array}$ & $\begin{array}{c}912 \\
(54.5 \%)\end{array}$ & $\begin{array}{c}2500 \\
(72.7 \%)\end{array}$ & $\begin{array}{c}1068 \\
(54.5 \%)\end{array}$ \\
\hline 3 & 8 & $\begin{array}{c}691 \\
(50.0 \%) \\
\end{array}$ & $\begin{array}{c}480 \\
(25.0 \%) \\
\end{array}$ & $\begin{array}{c}2414 \\
(75.0 \%) \\
\end{array}$ & $\begin{array}{c}2858 \\
(62.5 \%) \\
\end{array}$ \\
\hline 4 & 3 & $\begin{array}{c}738 \\
(100.0 \%)\end{array}$ & $\begin{array}{c}816 \\
(33.3 \%) \\
\end{array}$ & $\begin{array}{c}1088 \\
(66.6 \%)\end{array}$ & $\begin{array}{c}2984 \\
(33.3 \%)\end{array}$ \\
\hline 5 & 1 & $\begin{array}{c}982 \\
(100.0 \%)\end{array}$ & $\begin{array}{c}925 \\
(100.0 \%)\end{array}$ & $\begin{array}{c}1314 \\
(100.0 \%)\end{array}$ & $\begin{array}{c}356 \\
(0.0 \%)\end{array}$ \\
\hline Mean & 35 & $\begin{array}{c}951 \\
(80.0 \%)\end{array}$ & $\begin{array}{c}851 \\
(45.7 \%)\end{array}$ & $\begin{array}{c}1532 \\
(54.2 \%)\end{array}$ & $\begin{array}{c}1760 \\
(48.5 \%)\end{array}$ \\
\hline
\end{tabular}

G2 had a reduction of $27.3 \%$ and $18.1 \%$ in the SCC and TBC values, respectively. This highlights improved hygienic-sanitary managements, although these practices remained inefficient. Despites having high daily production, this group still had hygienicsanitary practice failures and mammary glands with poor sanitary conditions, which were very similar to some of the G1 properties.
In G3, which was similar to G2, similar SCC and $\mathrm{TBC}$ scores were found at both collections. The high bacteria counts are due to problems in hygienic-sanitary management, which induces bacterial contamination of the milk with various spoilage agents that can cause infections in consumers. Animals belonging to systems of this group were of excellent health, which translated to a low somatic cell count. The quantification of cells 
present in milk is a good way to track the health of the udder, and can indicate possible reductions in milk production and changes in the physical and chemical composition of the milk (ANDRADE et al., 2001).

Cunha et al. (2008) emphasize that reduced output caused by mastitis occurs due to changes in the secretory epithelial cells and vascular permeability of the alveoli during infection, and the severity of the loss is influenced by the gravity of the infection, the microorganism type, the length of the infection, animal age, the season, nutritional status and genetic potential.

G4 included SPLs below the required limits (SCC and TBC values at the second collection were $66.6 \%$ ), but they had high total bacterial counts during the second collection. These numbers represent difficulties applying hygienicsanitary practices in one SPL. In the G5 SPL, the
TBC diminished between collections, but wasn't followed by an improvement in hygienic-sanitary management because this property has is unable to perform hygienic practices. The TBC may have been reduced because of low rates of contamination or an improvement in hygiene at the time of the second collection.

Bodenmüller Filho et al. (2010) evaluated the types of systems and the characteristics of milk, and obtained SCC and TBC scores between 250-1321 cells $/ \mathrm{mL}^{-1}$ and $762-7600 \mathrm{CFU} / \mathrm{mL}^{-1}$, respectively, in 17 different groups, and these results are consistent with the findings of this study.

The selected points of contamination are critical because they represent important milk contamination pathways. The contamination observed in the various groups at the point of contamination are presented in Table 2.

Table 2. Average contamination by staphylococci (CFU / cm2; CFU / hand or CFU / $\mathrm{mL}$ ) in points of sample collection; set of milking machine (liner), milker's hand, storage tank and milk by groups (cluster).

\begin{tabular}{cccccc}
\hline Groups & Properties & Tear cup $^{\mathbf{1}}$ & Hand $^{\mathbf{2}}$ & Tank $^{\mathbf{3}}$ & Milk \\
\hline $\mathbf{1}$ & 12 & 9.34 & $8.7 \times 10^{3}$ & 24 & $3.8 \times 10^{3}$ \\
\hline $\mathbf{2}$ & 11 & $2.12 \times 10^{2}$ & $1.2 \times 10^{4}$ & 40 & $6.8 \times 10^{3}$ \\
\hline $\mathbf{3}$ & 8 & $1.69 \times 10^{2}$ & $1.5 \times 10^{4}$ & 72 & $4.3 \times 10^{3}$ \\
\hline $\mathbf{4}$ & 3 & 6.79 & $7.4 \times 10^{4}$ & 0.2 & $2.9 \times 10^{3}$ \\
\hline $\mathbf{5}$ & 1 & 0 & $1.2 \times 10^{3}$ & 1.06 & $1.2 \times 10^{3}$ \\
\hline Mean & 35 & $9.9 \times 10^{1}$ & $2.2 \times 10^{4}$ & 28 & $3.8 \times 10^{3}$ \\
\hline
\end{tabular}

1 Milking area $-117.75 \mathrm{~cm}^{2}$ (OLIVEIRA et al., 2007b).

2 Contamination by the milker's hand (SILVA et al., 2011).

3 Storage tank area $-500 \mathrm{~cm}^{2}$ (SILVA et al., 2011).

The SPLs in the fourth group had high production potential, leading to lower contamination of the milking machines due to adequate cleaning of the equipment: $100 \%$ of the owners used alkaline and acid cleaners, and the milking machines and utensils were serviced every six months.

The SPLs in G2 and G3 did not use detergents or sanitizers, resulting in high levels of contamination. In G1, $91.66 \%$ of the SPLs used detergents, alkaline and acid in the cleaning and sanitizing of milking equipment. In G2 and G3, the majority of SPLs weren't using any cleaning products, and did not have proper cleaning techniques, which caused higher contamination rates of the milking equipment.

Groups 1,2 and 3 had similar contamination levels of $8.7 \times 10^{3} \quad 1.2 \times 10^{4}$ and $1.5 \times 10^{4} \mathrm{CFU} /$ hand, respectively; despite carrying out different 
hygienic-sanitary practices. According to Miguel et al. (2012), the Staphylococcus aureus (S. aureus) is transmitting mainly by the hands of the milker and the milking equipment, which are important points of contamination control for the prevention of clinical and subclinical mastitis in animals. Fontana et al. (2012) found that 33\% of milker's hands were contaminated with $S$. aureus, which is below the prevalence obtained in this research in which $97.25 \%$ of SPLs had hand contamination. The reason for the high rates of contamination with Staphylococcus sp. is that a large number of SPLs did not perform hand cleaning properly, $40 \%$ of the milkers did not wash their hands before milking and only $5.71 \%$ washed their hands with soap and water before milking each animal.

In G4, the hands of the milkers had the highest infection rates, with $7.4 \times 10^{4} \mathrm{CFU} /$ hand. Only 33\% of SPLs had workers who washed their hands with water before handling each animal. In addition to being a very important disseminator for mastitis, such a procedure was performed incorrectly or not performed $(66 \%)$, and consequently resulted in higher contamination rates. Silva et al. (2011) and Matsubara et al. (2011) found coagulase-positive staphylococci contamination of milkers' hands prior to and after milking, with values of $8.7 \times 105.6 \times 10^{2}$ and $3.3 \times 10^{1}$ and $3.3 \mathrm{CFU} /$ hand, respectively. The contamination levels were elevated primarily in groups 2, 3 and 4, in which hand hygiene techniques were performed incorrectly.

The contamination observed in the cooling tanks was different between two groups, with similarities among groups 1, 2 and 3 (24.0; 40.0 and 72.0 CFU/ $\mathrm{cm}^{2}$ ), and 4 and 5 (1.06 and $0.2 \mathrm{CFU} / \mathrm{cm}^{2)}$. Group 5 had proper hygiene: the tank was sanitized every time milk was collected. Consequently, this practice improved the quality rating at this contamination point.

Group 4 had the lowest rates of contamination in the cooling tanks, $0.2 \mathrm{CFU} / \mathrm{cm}^{2}$ of staphylococci, which were driven by milk collection and tank cleaning practices, which were held at every output of milk with sanitizer (33\%) and no sanitizer (66\%), and there was milk collection every four $(66 \%)$ and every two (33\%) milkings. The hygienicsanitary management practices were carried out correctly in this group and positively influenced the results. Tebaldi et al. (2006) found cooling tank contamination with coagulase-positive staphylococci at levels of $2.7 \times 10^{4}$ to $1.73 \times 10^{7}$ $\mathrm{CFU} / \mathrm{mL}$, and suggested that although hygiene procedures result in lower fecal contamination, these microorganisms can pose problems for the health of the herd at any time.

One of the main problems of high Staphylococci counts is related to the possibility of producing enterotoxins. According to the FDA (1992), concentrations of enterotoxins above $10 \mathrm{~mL}$ of ${ }^{5} \mathrm{CFU}$ of $S$. aureus can cause symptoms of intoxication and can be resistant to the pasteurization process. In this study, only three SPLs (2 cooling tanks and one milker's hand) exceeded bacterial concentrations of $10^{5} \mathrm{CFU} \mathrm{mL}$, which is a satisfactory result and illustrates the importance of management and hygiene and sanitation in the control of the microorganism contamination.

Groups 1, 2 and 3 had very similar contamination levels regardless of variations in their management practices. In group 1, the cleaning of the tank was performed without sanitizing product in 50\% of properties and was sanitized after milk delivery in $33 \%$ of facilities. In group 2, 45\% of tank cleaning was performed without sanitizing product and only $18 \%$ were sanitized before and after milk delivery. In group 3, 37.5\% of tank cleaning was performed without sanitizing product and only $12.5 \%$ were sanitized at every milk delivery. The minor contamination observed in group 1 can be explained by the higher percentage of properties using sanitizers for cleaning the tanks, which is associated with the lower lengths of storage and the practice of cleaning utensils. The purpose of using sanitizers in milking systems is to reduce the existing bacterial contamination between milkings (CAVALCANTI et al., 2010). 
Vallin et al. (2009) emphasize the importance of the temperature and length of milk storage, together with inadequate sanitization, as these factors can have sharp fluctuations that directly affect the quality of refrigerated milk due to increased bacterial counts.

Regardless of the milk storage period, in group 3 , the largest range between milk delivery was observed: $50 \%$ of the properties had the milk collected every 48 hours and the other $50 \%$ had 60 hour intervals between each delivery. In groups 1 and 2, the delivery was performed every 24 hours in $33 \%$ and $36 \%$ of facilities, respectively, and every 48 hours for $66 \%$ and $64 \%$ of the properties, respectively. The longer the storage time, the higher the multiplication of microorganisms. As such, group 3 had higher infection rates in the cooling tank, and this contamination may have also been favored by the lower percentage of cooling tank cleaning practices. The extended time between collections facilitates the multiplying of the microbial load in the milk, thereby decreasing the final quality of the raw milk.

The longer the storage time, the higher the multiplication of the contaminants. As such, group 3 had higher contamination rates in the tank. The extended time between collections favors the proliferation of the microbial load in the milk, thereby decreasing the final quality.

Other variables such as the treatment of cases of clinical mastitis, sanitizing practices and discarding mastitic milk directly influence the final contamination of the milk. The cooling tank is the final destination of the milk, and its hygiene must be properly maintained to minimize contamination and microbial growth.

The milk contamination rates were similar for all groups, with group 5 having the lowest contamination rate of $1.2 \times 10^{3} \mathrm{CFU} / \mathrm{mL}$ and group 2 having the highest contamination rate $\left(6.8 \times 10^{3} \mathrm{CFU} /\right.$ $\mathrm{mL})$. The final contamination of milk is dependent on the hygiene and health management practices. Direct and indirect interference in the type and amount of contamination agents reduces the quality of the final product and damages industrialization and dairy products.

Arcuri et al. (2006) found that 91.27\% of refrigerated raw milk had $S$. aureus from the dairy herds of Minas Gerais, and they highlighted the problems of possible contamination in the mammary gland, deficiencies in mastitis control, failures in adherence to hygienic procedures during milking, and contamination of the milkers' hands and milking equipment.

Our results corroborate with those of Lamaita et al. (2005), who found Staphylococci in 100\% of properties with contamination rates ranging from $1.0 \times 10^{5}$ to $>1.1 \times 10^{7} \mathrm{CFU} / \mathrm{mL}$ in refrigerated raw milk. These contamination rates suggest high rates of animals with mastitis, the presence of asymptomatic carriers and inefficient milk cooling after milking.

\section{Conclusion}

Critical control points are crucial evidence of their importance in the monitoring and reduction of specific agents such as Staphylococcus sp., and they suggest failures in milking hygiene activities and the contamination of milkers' hands, resulting in contamination that may cause serious losses throughout the production process. The evaluated hygienic and sanitary management practices and their practices suggest the importance of preventive measures for improving milk quality, which reduce the microbial contamination and increase quality.

\section{References}

ANDRADE, P. V. D.; SOUZA, M. R.; BORGES, I.; PENNA, C. F. A. M. Contagem de células somáticas em leite de cabra. Arquivos Brasileiros de Medicina Veterinária e Zootecnia, Belo Horizonte, v. 53, n. 3, p. 396-400, jun. 2001. 
ANDRADE, U. V. C.; HARTMANN, W.; MASSON, M. L. Isolamento microbiológico, contagem de células somáticas e contagem bacteriana total em amostras de leite. ARS Veterinária, Jaboticabal, v. 25, n. 3, p. 129135, 2009.

ARCURI, E. F.; BRITO, M. A. V. P.; BRITO, J. R. F.; PINTO, S. M.; ÂNGELO, F. F.; SOUZA, G. N. Qualidade microbiológica do leite refrigerado nas fazendas. Arquivos Brasileiros de Medicina Veterinária e Zootecnia, Belo Horizonte, v. 58, n. 3, p. 440-446, 2006.

BODENMÜLLER FILHO, A.; DAMASCENO, J. C.; PREVIDELLI, I. T. S.; SANTANA, R. G.; RAMOS, C. E. C. O.; SANTOS, G. T. Tipologia de sistemas de produção baseada nas características do leite. Revista Brasileira de Zootecnia, Viçosa, MG, v. 39, n. 8, p. 18321839, 2010.

BRASIL. Ministério da Agricultura e Abastecimento. Instrução Normativa ${ }^{\circ}$ 62, de 29 de dezembro de 2011. Regulamento técnico de identidade e Qualidade do Leite Cru Refrigerado. In: BRASIL. Ministério da Agricultura, Pecuária e Abastecimento. Diário Oficial [da] União, 29 dez. 2011. Seção 1, p. 13-14, 2011.

BRITO, J. R. F.; BRITO, M. A. V. P. Qualidade higiênica do leite. Juiz de Fora: EMBRAPA-CNPGL-ADT, 1998. $17 \mathrm{p}$.

CAVALCANTI，E. R. C.; CAVALCANTI，M. R.; SOUZA, W. J.; ARAÚJO, D. G. Avaliação microbiológica em ordenhadeira mecânica antes e após adoção de procedimento orientado de higienização. Revista Brasileira de Ciências Veterinárias, Rio de Janeiro, v. 17, n. 1, p. 3-6, jan./abr. 2010.

CERQUEIRA, M. M. O. P.; PICININ, L. C. A.; FONSECA, L. M.; SOUZA, M. R.; LEITE, M. O.; PENNA, C. F. A. M. Qualidade da água e seu impacto na qualidade microbiológica do leite. In: MESQUITA, A. J.; DURR, J. W.; COELHO, K. O. Perspectivas e avanços da qualidade do leite no Brasil. Goiânia: Talento, 2006. v. 1 , p. $273-290$.

CUNHA, J. E.; MORESCO, M. D. Características pedomorfológicas da topossequência de solos frentino de Marechal Cândido Rondon - PR: suas relações e implicações nos processos erosivos. In: SIMPÓSIO BRASILEIRO DE GEOGRAFIA FÍSICA APLICADA, 10., 2003, Rio de Janeiro. Anais... Rio de Janeiro: UERJ, 2003. p. 230.

CUNHA, R. P. L.; MOLINA, L. R.; CARVALHO, A. U.; FACURY FILHO, E. J.; FERREIRA, P. M.; GENTILINI, M. B. Mastite subclínica e relação da contagem de células somáticas com número de lactações, produção e composição química do leite em vacas da raça Holandesa. Arquivos Brasileiros de Medicina Veterinária e Zootecnia, Belo Horizonte, v. 60, n. 1, p. 19-24, 2008.

DAMASCENO, J. C.; BOUNDERMÜLLER FILHO,
A.; RAMOS, C. E. C. O.; SANTOS, J. C.; SANTOS, G. T. O papel do homem na gestão e controle de qualidade da produção de leite. In: SANTOS, G. T.; UHLIG, L.; BRANCO, A. F.; JOBIM, C. C.; DAMASCENO, J. C.; CECATO, U. (Ed.). Inovação tecnológica na cadeia produtiva do leite e a sustentabilidade da pecuária leiteira. Maringá: Eduem, 2008. p. 271-284.

DEDIEU, B.; CHABANET, G.; JOSIEN, E.; BÉCHEREL, F. Organisation du pâturage et situations contraignantes en travail: démarche d'étude et examples en élevage bovin viande. Fourrages, v. 149, p. 21-36. 1997.

FDA, U.S. Food and Drug Administration. Foodborne pathogenic microorganisms and natural toxins: Center for Food Safety and Applied Nutrition. Rockville, Maryland, 1992. p. 12-16.

FONSECA, L. F. L.; SANTOS, M. V. Qualidade do leite e controle da mastite. São Paulo: Lemos, 2001. 175 p.

FONTANA, V. L. D. S.; GIANNINI, M. J. S. M.; FONTANA, C. A. P.; STELlA, A. E. Caracterização molecular de estafilococos isolados de vacas com mastite subclínica e ordenhadores. Arquivos Institucionais de Biologia, São Paulo, v. 79, n. 4, p. 469-476, out./dez. 2012.

GUERREIRO, P. K.; MACHADO, M. R. F.; BRAGA, G. C.; GASPARINO, E.; FRANZENER, A. S. M. Qualidade microbiológica de leite em função de técnicas profiláticas no manejo de produção. Ciência e Agrotecnologia, Lavras, v. 29, n. 1, p. 216-222, jan./fev. 2005.

GONZALEZ, H. L.; FISCHER, V.; RIBEIRO, M. E. R.; GOMES, J. F.; STUMPF JÚNIOR, W.; SILVA, M. A. da Avaliação da qualidade do leite na bacia leiteira de Pelotas, RS. Efeito dos meses do ano. Revista Brasileira de Zootecnia, v. 33, n. 6, p. 1531-1543, 2004.

INSTITUTO AGRONÔMICO DO ESTADO DO PARANÁ - IAPAR. Cartas climáticas do Estado do Paraná 1994. Londrina: IAPAR, 1994, 49 p.

KUBRUSLY, L. S. Um procedimento para calcular índices a partir de uma base de dados multivariados. Pesquisa Operacional, Rio de Janeiro, v. 21, n. 1, p. 107117, 2001.

LAMAITA, H. C.; CERQUEIRA, M. M. O. P.; CARMO, L. S.; SANTOS, D. A.; PENNA, C. F. A. M.; SOUZA, M. R. Contagem de Staphylococcis sp. e detecção de enterotoxinas e toxina da síndrome do choque tóxico em amostras de leite cru refrigerado. Arquivos Brasileiros de Medicina Veterinária e Zootecnia, Belo Horizonte, v. 57, n. 5, p. 702-709, 2005.

LOPES JUNIOR, J. F.; RAMOS, C. E. C. O.; SANTOS, G. T. dos; GRANDE, P. A.; DAMASCENO, J. C.; MASSUDA, E. M. Análise das práticas de produtores em sistemas de produção leiteiros e seus resultados na produção e qualidade do leite. Semina: Ciências 
Agrárias, Londrina, v. 33, n. 3, p. 1199-1208, maio/jun. 2012.

MACHADO, P. F.; PEREIRA, A. R.; SARRÍES, G. A. Composição do leite de tanques de rebanhos brasileiros distribuídos segundo sua contagem de células somáticas. Revista Brasileira de Zootecnia, Viçosa, MG, v. 29, n. 6, p. 1883-1886, 2000.

MATSUBARA, M. T.; BELOTI, V.; TAMANINI, R.; FAGNANI, R.; SILVA, L. C. C.; MONTEIRO, A. A.; BATTAGLINI, A. P. P.; ORTOLANI, M. B. T.; BARROS, M. A. F. Boas práticas de ordenha para redução da contaminação microbiológica do leite no agreste Pernambucano. Semina: Ciências Agrárias, Londrina, v. 32, n. 1, p. 277-286, jan./mar. 2011.

MIGUEL, P. R. R.; POZZA, M. S. S.; CARON, L. F.; ZAMBOM, M. A.; POZZA, P. C. Incidência de contaminação no processo de obtenção do leite e suscetibilidade a agentes antimicrobianos. Semina: Ciências Agrárias, Londrina, v. 33, n. 1, p. 403-416, jan./ mar. 2012.

MÜLLER, E. E. Qualidade do leite, células somáticas e prevenção da mastite. In: SUL - LEITE: SIMPÓSIO SOBRE SUSTENTABILIDADE DA PECUÁRIA LEITEIRA NA REGIÃO SUL DO BRASIL, 2., 2002, Maringá. Anais... Maringá: UEM/CCA/DZO - NUPEL, 2002. p. 206-217.

NERO, L. A.; VIÇOSA, G. N.; PEREIRA, F. E. V. Qualidade microbiológica do leite determinada por característica de produção. Ciência e Tecnologia de Alimentos, Campinas, v. 29, n. 2, p. 386-390, abr.jun. 2009.

OLIVEIRA, A. S.; CUNHA, D. N. F. V.; CAMPOS, J. M. S.; VALE, S. M. R.; ASSIS, A. J. Identificação e quantificação de indicadores-referência de sistemas de produção de leite. Revista Brasileira de Zootecnia, Viçosa, MG, v. 36, n. 2, p. 507-516, 2007 a.

OLIVEIRA, M. M. de; BRUGNERA, D. F.; PICOLLI, R. H. Avaliação da qualidade microbiológica do leite cru e eficiência de ordenha mecânica de pequenas propriedades leiteiras do município de Campo Belo MG. In: CONGRESSO NACIONAL DE LATICÍNIOS. REVISTA DO INSTITUTO DE LATICÍNIOS CÂNDIDO TOSTES, 24., 2007, Juiz de Fora. Anais... Juiz de Fora: EPAMIG/ILCT, 2007b. v. 62, n. 357, p. 124-130.

PARANÁ. Superintendência de Desenvolvimento de Recursos Hídricos e Saneamento Ambiental. Atlas de Recursos Hídricos do Estado do Paraná. Curitiba, 1998. p. 32 .

PERIN, O. R.; FERREIRA, G. M. V.; TALAMINI, E. Percepção de qualidade no processo produtivo do leite: um estudo de caso no Rio Grande do Sul. Organizações
Rurais \& Agroindustriais, Lavras, v. 11, n. 3, p. 436-451, 2009.

REIS, G. L.; ALVES, A. A.; LANA, A. M. Q.; COELHO, S. G.; SOUZA, M. R.; CERQUEIRA, M. M. P.; PENNA, C. F. A. M.; MENDES, E. D. M. Procedimentos de coleta de leite cru individual e sua relação com a composição físico-química e a contagem de células somáticas. Ciência Rural, Santa Maria, v. 37, n. 4, p. 1134-1138, jul./ago. 2007.

SANTOS, M. V.; FONSECA, L. F. L. Importância e efeito de bactérias psicrotróficas sobre a qualidade do leite. Revista Higiene Alimentar, São Paulo, v. 15, n. 82, p. 13-19, 2001.

SILVA, E. M. N.; SOUZA, B. B.; SILVA, G. A.; AZEVEDO, S. S.; MARQUE, B. A. A.; GOMES, T. L. S. Diagnóstico dos sistemas de produção de leite de cabra no município de Sumé cariri da Paraíba. Revista Agropecuário Científico do Semiárido, Patos, PB, v. 9, n. 2, p. 61-65, abr.jun. 2013.

SILVA, L. C. C.; BELOTI, V.; TAMANINI, R.; OVIDIO, L.; MATTOS, M. R.; ARRUDA, A. M. C. T.; PIRES, E. M. F. Rastreamento de fontes de contaminação microbiológica do leite cru durante a ordenha em propriedades leiteiras do Agreste Pernambucano. Semina: Ciências Agrárias, Londrina, v. 32, n. 1, p. $267-$ 276, jan./mar. 2011.

SOLANO, C.; BERNUÉS, A.; ROJAS, F.; JOAQUÍN, N.; FERNANDEZ, W.; HERRERO, M. Relationships between management intensity and structural and social variables in dairy and dual-purpose systems in Santa Cruz, Bolivia. Agricultural Systems, Santa Cruz, v. 65, n. 3, p. 159-177, 2000.

TEBALDI, V. M. R.; OLIVEIRA, T. L. C.; BOARI, C. A.; PICCOLI, R. H. Isolamento de coliformes, estafilococos e enterococos de leite cru provenientes de tanques de refrigeração por expansão comunitários: identificação, ação lipolítica e proteolítica. Ciência e Tecnologia de Alimentos, Campinas, v. 28, n. 3, p. 753-760, jul./set. 2006.

VALEEVA, N. I., MEUWISSEN, M. P. M.; BERGEVOET, R. H. M.; OUDE LANSINK, A. G. J. M.; HUIRNE, R. B. M. Improving food safety at the dairy farm level: farmers' and experts' perceptions. Review of Agricultural Economics, Oxford, v. 27, n. 4, p. 574-592, 2005.

VALLIN, V. M.; BELOTI, V.; BATTGLINI, A. M. P.; TAMANINI, R.; FAGNANI, R.; ANGELA, H. L.; SILVA, L. C. C. Melhoria da qualidade do leite a partir da implantação de boas práticas de higiene na ordenha em 19 municípios da região central do Paraná. Semina: Ciências Agrárias, Londrina, v. 30, n. 1, p. 181-188, jan./ mar. 2009. 